\title{
PENGARUH PENAMBAHAN TEH HIJAU TERHADAP AKTIVITAS ANTIOKSIDAN DAN KADAR PROTEIN MINUMAN FUNGSIONAL SUSU KEDELAI DAN MADU
}

\author{
Dian Isti Cahyani, Ninik Rustanti*) \\ Program Studi Ilmu Gizi Fakultas Kedokteran Universitas Diponegoro \\ Jl.Dr.Sutomo No.18, Semarang, Telp (024) 8453708, Email : gizifk@ undip.ac.id
}

\begin{abstract}
Background : Consumption of antioxidant food sources in sufficient amount to prevent the risk of hypercholesterolemia. Antioxidants can inhibit lipid peroxide by free radicals. Green tea, soybean and honey are natural sources of antioxidants that can be used as functional drinks as prevention of hypercholesterolemia.

Objective : To analyze the effect of green tea addings on antioxidant activity, protein and organoleptic aspect that include color, aroma and flavor of soy milk and honey functional drink.

Method : A completely randomized single factor-experimental study by green tea addings (0\%; 2\%; 3\% and 4\%) on soy milk and honey functional drink. Statistical analysis of antioxidant activity and protein data used One Way ANOVA followed by Tukey test, while organoleptic data was analyzed by Friedman test followed by Wilcoxon test.

Result : The antioxidant activity of functional drinks in the treatment drinks lower than the control drinks with the addition of $4 \%$ which is $13,15 \%$ and the highest protein content with the addition of $4 \%$ which is $4,12 \%$. In organoleptic terms of color, aroma and taste less favored treatment drinks.

Conclusion : Green tea addings on soy milk and honey functional decreassed antioxidant activity and increased protein were significantly.
\end{abstract}

Keyword : functional drink, soy milk, honey, green tea, antioxidant activity

\section{ABSTRAK}

Latar Belakang : Konsumsi bahan pangan sumber antioksidan dalam jumlah memadai dapat mencegah risiko hiperkolesterolemia. Antioksidan dapat menghambat peroksida lipid akibat radikal bebas. Teh hijau, kedelai dan madu merupakan bahan alami tinggi antioksidan yang dapat dijadikan bahan minuman fungsional mencegah hiperkolesterolemia.

Tujuan : Menganalisis pengaruh penambahan teh hijau terhadap aktivitas antioksidan, protein dan organoleptik yang meliputi warna, aroma dan rasa minuman fungsional susu kedelai dan madu

Metode : Merupakan penelitian eksperimental rancangan acak satu faktor yaitu penambahan teh hijau $(0 \%, 2 \%, 3 \%$, $4 \%)$ pada pembuatan minuman fungsional susu kedelai dan madu. Analisis aktivitas antioksidan dan protein menggunakan One Way ANOVA dilanjutkan uji Tukey, sedangkan analisis organoleptik menggunakan uji Friedman dilanjutkan uji Wilcoxon.

Hasil : Aktivitas antioksidan minuman fungsional pada minuman perlakuan lebih rendah daripada minuman kontrol dengan penambahan $4 \%$ yakni 13,15\% dan kadar protein tertinggi dengan penambahan 4\% yakni 4,12\%. Secara organoleptik dari segi warna, aroma dan rasa minuman perlakuan kurang disukai.

Simpulan : Penambahan teh hijau pada minuman fungsional susu kedelai dan madu menurunkan aktivitas antioksidan dan menaikkan kadar protein yang bermakna secara statistik.

Kata kunci : minuman fungsional, susu kedelai, madu, teh hijau, aktivitas antioksidan

\section{PENDAHULUAN}

Penyakit Kardiovaskuler atau Cardiovascular diseases (CVDs) merupakan penyebab nomor satu kasus kematian secara global. Menurut World Health Organization (WHO), diperkirakan 17,3 juta orang meninggal akibat CVD pada tahun 2008, mewakili $30 \%$ dari kematian secara global. ${ }^{1}$ Diperkirakan 7,3 juta orang meninggal karena penyakit jantung koroner. ${ }^{2}$

Salah satu faktor risiko terjadinya penyakit jantung koroner adalah kadar kolesterol yang tinggi atau disebut hiperkolesterolemia. Menurut data WHO pada tahun 2002, tercatat sebanyak 4,4 juta kematian karena penyakit jantung koroner (PJK) disebabkan karena hiperkolesterolemia. ${ }^{3}$ Pada keadaan hiperkolesterolemia terjadi peningkatan kadar kolesterol Low Density Lipoprotein (LDL). Jika radikal bebas menyerang LDL, maka akan menginduksi terjadinya peroksidasi. LDL yang telah teroksidasi ini akan difagositosis oleh makrofag membentuk sel busa. Sel busa adalah tanda awal terjadinya penyakit jantung koroner. ${ }^{4} \mathrm{Sel}$ busa yang tebentuk akibat oksidasi LDL dapat dihambat dengan antioksidan.

Selain antioksidan, protein juga berperan penting dalam mencegah penyakit jantung koroner. Kebutuhan protein cukup 10-20\% dari kebutuhan energi total. Dalam sebuah studi crossover, subjek 
dengan hiperkolesterolemia moderat diberikan asupan tinggi protein $(23 \%$ energi) dan rendah karbohidrat (53\% energi) dengan rendah protein (11\% energi) dan tinggi karbohidrat (65\% energi) selama 4-5 minggu. Pertukaran protein dengan karbohidrat secara signifikan menurunkan kolesterol LDL $(6,4 \%)$ dan triasilgliserol $(23 \%)$, serta meningkatkan HDL $(12 \%) .{ }^{20}$ Dalam sebuah artikel hasil penelitian di USA, disebutkan 730 orang mengkonsumsi protein kedelai dan menunjukkan adanya penurunan kolesterol total $9,3 \%$, LDL $12,9 \%$, trigliserida $10,5 \%$, sementara HDL meningkat $2,4 \% .^{21}$

Antioksidan merupakan senyawa yang dapat menghambat reaksi oksidasi, dengan mengikat radikal bebas. Tubuh manusia secara alami mempunyai antioksidan alami (antioksidan endogen) berupa enzim-enzim yang disintesis oleh tubuh, seperti superoksida dismutase (SOD), katalase dan glutation peroksidase..$^{5}$ Tetapi dalam keadaan patologik akibat terpapar radikal bebas yang dapat merugikan tubuh, enzim-enzim yang berfungsi sebagai antioksidan endogen menurun aktivitasnya. Oleh karena itu, diperlukan antioksidan yang berasal dari luar tubuh (antioksidan eksogen) pada umumnya dapat diperoleh dari konsumsi bahan pangan. Sumber antioksidan alami berasal dari senyawa fenol seperti golongan flavonoid.

Kedelai memiliki kandungan flavonoid. Salah satu komponen senyawa bioaktif yang berfungsi sebagai antioksidan dalam kedelai adalah isoflavon. Isoflavon pada olahan kedelai nonfermentasi pada umumnya dalam bentuk glikosida, yaitu $64 \%$ genistein, $23 \%$ daidzein, dan $13 \%$ glisitein. ${ }^{7}$ Salah satu olahan kedelai non fermentasi adalah susu kedelai. Susu kedelai lebih dikenal sebagai susu alternatif pengganti susu sapi karena kandungan protein yang cukup tinggi yaitu $4,4 \%$ dan tidak mengandung laktosa. ${ }^{6}$

Sumber antioksidan lainnya yaitu madu. Madu merupakan pemanis alami yang penyusun utamanya fruktosa. Madu mengandung berbagai zat gizi penting, seperti oligosakarida yang tidak dapat dicerna (non-digestible oligosaccharides/NDOs), antioksidan, vitamin dan mineral. Kandungan nutrisi madu yang berfungsi sebagai antioksidan adalah vitamin $\mathrm{C}$, asam organik, asam fenolat, flavonoid dan beta-karoten. ${ }^{12}$

Teh hijau mengandung senyawa polifenol yang bermanfaat sebagai antioksidan. Kandungan polifenol dalam teh hijau antara lain flavanol, flavonoid dan asam fenolik (hingga 30\% dari berat kering). Flavonoid yang paling penting adalah katekin (kandungan sekitar 10\% dari berat kering). ${ }^{9}$ Kandungan utama katekin pada teh hijau yaitu epikatekin (EC), epikatekin galat (ECG), epikgalokatekin (EGC), dan epigalokatekin galat (EGCG). ${ }^{8}$ Sebuah penelitian menemukan bahwa diantara kandungan polifenol dalam teh hijau terutama epigalokatekin galat (EGCG) secara signifikan mengurangi asupan makan, berat badan, kolesterol dan trigliserida. ${ }^{10}$

Teh hijau bubuk atau matcha didefinisikan sebagai teh hijau giling dengan ukuran partikel kurang dari $76 \mu \mathrm{m} .{ }^{26}$ Proses tersebut berpengaruh pada komposisi kimia dari teh hijau seperti polifenol, asam amino dan kafein masih asli. Teh hijau yang akan dijadikan matcha terbuat dari tunas muda dari tanaman teh yang tumbuh di tempat yang teduh (shading) atau tidak terkena sinar matahari langsung. ${ }^{22}$ Alasan dari shading ini adalah untuk meningkatkan produksi klorofil dengan mengurangi fotosintesis di daun. ${ }^{22}$ Dalam sebuah penelitian menunjukkan bahwa konsentrasi EGCG pada matcha 137 kali lebih besar dibandingkan dengan teh hijau biasa. ${ }^{11}$

Berdasarkan uraian di atas, dilakukan penelitian yang menganalisis aktivitas antioksidan, kadar protein dan organoleptik minuman fungsional susu kedelai dan madu dengan penambahan teh hijau.

\section{METODE PENELITIAN}

Penelitian yang dilakukan termasuk dalam bidang food production. Penelitian dilakukan mulai bulan Maret sampai Juni di Laboratorium Gizi dan Kimia Pangan Fakultas Peternakan Universitas Diponegoro dan di Program Studi Ilmu Gizi Universitas Diponegoro Semarang.

Penelitian ini merupakan penelitian eksperimental dengan rancangan acak lengkap satu faktor yaitu penambahan teh hijau (Camellia sinensis) pada minuman fungsional susu kedelai (Glycine max (L) Merill) dan madu (Apis Dorsata). Terdapat 4 taraf perlakuan $(\mathrm{t}=4)$ yaitu penambahan teh hijau 0\% (kontrol), 2\%, 3\% dan 4\%. Tiap kelompok perlakuan pada penelitian ini dilakukan 3 kali pengulangan sehingga diperoleh 12 satuan percobaan. Penentuan formulasi teh hijau, susu kedelai dan madu pada minuman fungsional dilakukan melalui penelitian pendahuluan.

Berdasarkan uji organoleptik terbaik, ditentukan formulasi minuman fungsional teh hijau, susu kedelai dan madu sebagai berikut. 
Tabel 1. Formulasi Minuman Fungsional Teh Hijau, Susu Kedelai dan Madu

\begin{tabular}{cccc}
\hline Perlakuan & $\begin{array}{c}\text { Penambahan teh } \\
\text { hijau (\%) }\end{array}$ & $\begin{array}{c}\text { Susu kedelai } \\
\text { (gram) }\end{array}$ & $\begin{array}{c}\text { Madu } \\
(\boldsymbol{\%})\end{array}$ \\
\hline $\mathrm{T}_{0}$ & 0 & 200 & 20 \\
$\mathrm{~T}_{1}$ & 2 & 200 & 20 \\
$\mathrm{~T}_{2}$ & 3 & 200 & 20 \\
$\mathrm{~T}_{3}$ & 4 & 200 & 20 \\
\hline
\end{tabular}

Bahan baku kedelai bermerk Superindo 365 diperoleh dari Supermarket Superindo Semarang, teh hijau bermerk Matcha Story diperoleh dari Bandung, dan madu hutan diperoleh dari peternak madu di Pontianak.

Tahap awal pembuatan minuman yaitu dengan membuat susu kedelai terlebih dahulu. Kedelai terlebih dahulu direndam selama \pm 8 jam, kemudian dibersihkan dari kotoran. Kemudian susu kedelai dibuat dengan metode penggilingan panas (hot grinding). Sebelum digiling, kedelai diblanching selama 15 menit, kemudian kedelai digiling dengan air bersuhu $80-90^{\circ} \mathrm{C}$, dengan perbandingan berat kering kedelai dan air panas 1:10. Setelah selesai digiling susu kedelai dipanaskan selama \pm 10 menit dan dinginkan. Setelah susu kedelai dingin, teh hijau yang berupa bubuk dan madu ditambahkan, kemudian diblender bersama. Prosedur pembuatan minuman fungsional dapat dilihat pada Lampiran 1.

Pada penelitian ini dilakukan pengumpulan data berupa aktivitas antioksidan dengan metode
ABTS (2,2'-azino-bis-[3-ethylbenzthiazoline-6sulfonic acid]), ${ }^{16}$ dan kadar protein dengan metode Lowry $^{14}$ yang dianalisis secara duplo serta organoleptik pada 25 panelis. ${ }^{15}$ Semua data yang terkumpul dianalisis menggunakan program SPSS 20. Pengaruh penambahan teh hijau pada minuman fungsional susu kedelai dan madu terhadap aktivitas antioksidan dan kadar protein diuji dengan One Way ANOVA dan dilanjukan dengan posthoc test Tukey untuk mengetahui beda nyata antar perlakuan. Pengaruh penambahan teh hijau terhadap tingkat kesukaan panelis pada parameter warna, aroma dan rasa diuji menggunakan uji Friedman dan uji lanjut Wilcoxon.

\section{HASIL}

\section{Aktivitas Antioksidan dan Kadar Protein Minuman Fungsional Teh Hijau, Kedelai dan Madu}

Hasil uji aktivitas antioksidan dan kadar protein teh hijau, susu kedelai dan madu dapat dilihat pada Tabel 2 .

Tabel 2. Aktivitas Antioksidan dan Protein Bahan Baku

\begin{tabular}{lcc}
\hline \multicolumn{1}{c}{ Bahan } & $\begin{array}{c}\text { Aktivitas Antioksidan } \\
(\mathbf{\%})\end{array}$ & $\begin{array}{c}\text { Protein } \\
(\boldsymbol{\%})\end{array}$ \\
\hline Teh Hijau & 9,74 & 18,18 \\
Susu Kedelai & 12,81 & 1,10 \\
Madu & 53,85 & 3,58
\end{tabular}

Teh hijau mempunyai aktivitas antioksidan terendah dibandingkan susu kedelai dan madu, yaitu $9,74 \%$, sedangkan susu kedelai dan madu yakni $12,81 \%$ dan $53,85 \%$. Kadar protein paling tinggi adalah teh hijau yaitu $18,18 \%$ sedangkan susu kedelai dan madu yaitu $1,10 \%$ dan $3,58 \%$.
Hasil analisis aktivitas antioksidan dan kadar protein minuman fungsional teh hijau, susu kedelai dan madu dapat dilihat pada Lampiran 2 dan Tabel 3.

Tabel 3. Aktivitas Antioksidan dan Kadar Protein Minuman Fungsional

\begin{tabular}{ccc}
\hline Perlakuan & $\begin{array}{c}\text { Aktivitas Antioksidan } \\
(\boldsymbol{\%})\end{array}$ & $\begin{array}{c}\text { Protein } \\
(\boldsymbol{\%})\end{array}$ \\
\hline $\mathrm{T}_{0}$ & $16,98 \pm 1,95^{\mathrm{a}}$ & $1,71 \pm 0,15^{\mathrm{d}}$ \\
$\mathrm{T}_{1}$ & $11,27 \pm 1,38^{\mathrm{b}}$ & $2,64 \pm 0,06^{\mathrm{c}}$ \\
$\mathrm{T}_{2}$ & $10,12 \pm 0,63^{\mathrm{b}}$ & $3,32 \pm 0,13^{\mathrm{b}}$ \\
$\mathrm{T}_{3}$ & $13,15 \pm 1,33^{\mathrm{b}}$ & $4,12 \pm 0,14^{\mathrm{a}}$ \\
\hline & $\mathrm{p}=0,005$ & $\mathrm{p}=0,000$ \\
\hline
\end{tabular}

Keterangan : Huruf yang berbeda (a,b,c,d) dibelakang angka menunjukkan adanya perbedaan nyata 
Berdasarkan hasil analisis data, penambahan teh hijau menurunkan aktivitas antioksidan minuman fungsional $(\mathrm{p}=0,002)$. Aktivitas antioksidan tidak berbeda nyata pada penambahan teh hijau 2\%, 3\% dan 4\%

Penambahan teh hijau meningkatkan kadar protein pada minuman fungsional $(\mathrm{p}=0,000)$.
Seiring semakin banyak teh hijau yang ditambahkan, kadar protein minuman meningkat.

Organoleptik Minuman Fungsional Teh Hijau, Susu Kedelai dan Madu

Hasil analisis tingkat kesukaan warna, aroma dan rasa minuman fungsional teh hijau, susu kedelai dan madu dapat dilihat pada Lampiran 3 dan Tabel 4.

Tabel 4. Organoleptik Warna, Aroma dan Rasa Minuman Fungsional

\begin{tabular}{|c|c|c|c|c|c|c|}
\hline \multirow{2}{*}{ Perlakuan } & \multicolumn{2}{|c|}{ Warna } & \multicolumn{2}{|c|}{ Aroma } & \multicolumn{2}{|c|}{ Rasa } \\
\hline & Rerata \pm std & Ket. & Rerata \pm std & Ket. & Rerata \pm std & Ket. \\
\hline $\mathrm{T}_{0}$ & $3,60 \pm 0,82$ & Suka & $4,00 \pm 0,81^{\mathrm{a}}$ & Suka & $3,84 \pm 1,02^{\mathrm{a}}$ & Suka \\
\hline $\mathrm{T}_{1}$ & $3,16 \pm 0,80$ & Netral & $3,32 \pm 0,80^{b}$ & Netral & $2,96 \pm 1,06^{\mathrm{b}}$ & Netral \\
\hline $\mathrm{T}_{2}$ & $3,44 \pm 0,76$ & Netral & $3,16 \pm 0,94^{b}$ & Netral & $2,24 \pm 0,66^{\mathrm{c}}$ & Tidak Suka \\
\hline $\mathrm{T}_{3}$ & $3,24 \pm 1,12$ & Netral & $3,12 \pm 1,20^{\mathrm{b}}$ & Netral & $2,04 \pm 0,79^{c}$ & Tidak Suka \\
\hline & $\mathrm{p}=0,373$ & & $\mathrm{p}=0,008$ & & $\mathrm{p}=0,000$ & \\
\hline
\end{tabular}

Keterangan : Huruf dibelakang angka $(a, b, c)$ menunjukkan adanya perbedaan yang nyata.

Berdasarkan hasil analisis data, penambahan teh hijau pada minuman fungsional dari parameter warna dinilai netral $(\mathrm{p}=0,373)$. Pada parameter aroma, penambahan teh hijau dinilai netral $(\mathrm{p}=0,008)$. Pada parameter rasa, semakin banyak penambahan teh hijau semakin kurang disukai $(\mathrm{p}=0,000)$.

\section{PEMBAHASAN}

\section{Aktivitas Antioksidan dan Kadar Protein Minuman Fungsional Teh Hijau, Susu Kedelai dan Madu \\ Aktivitas Antioksidan}

Secara umum aktivitas antioksidan pada minuman fungsional mengalami penurunan. Hal ini disebabkan aktivitas antioksidan pada minuman kontrol sebesar $16,98 \%$ yang lebih tinggi dibandingkan dengan minuman penambahan $2 \%$, $3 \%$ dan $4 \%$. Susu kedelai mengandung senyawa antioksidan berupa isoflavon, kemudian madu mengandung vitamin $\mathrm{C}$, asam organik, asam fenolat, flavonoid dan beta-karoten, ${ }^{12}$ sedangkan teh hijau mengandung katekin dengan epigalokatekin galat (EGCG) sebagai susunan terbanyak yaitu 48$55 \% .{ }^{30}$

Penurunan aktivitas antioksidan kemungkinan disebabkan ikatan antara katekin teh hijau dengan protein susu kedelai. Protein dalam susu kedelai (soya glycine dan soya trypsin inhibitor) dapat berperilaku mirip dengan kasein dalam susu sapi sehingga hasil dalam ikatan protein-katekin menurunkan aktivitas antioksidan. ${ }^{18}$ Kasein susu menutup kapasitas pencarian ABTS pada ekstrak teh hijau dan beberapa flavonoid murni dalam teh. ${ }^{17}$
Beberapa penelitian yang pernah dilakukan mengenai aktivitas antioksidan teh hijau dengan penambahan susu menyatakan aktivitas antioksidan pada teh hijau akan berkurang seiring dengan bertambahnya presentase penambahan susu. ${ }^{17,19,24,25}$ Penelitian terdahulu tentang susu kedelai dan teh yang menganalisa dan membandingkan aktivitas antioksidan teh hitam yang ditambahkan dengan susu kedelai kemudian dibandingkan dengan susu semi-skim, menunjukkan aktivitas antioksidan teh hitam pada penambahan susu kedelai menurun tetapi lebih tinggi dibandingkan dengan penambahan susu semi-skim. ${ }^{23}$ Namun, data tentang efek penambahan teh hijau pada antioksidan susu kedelai masih sedikit.

\section{Kadar Protein}

Penambahan teh hijau pada minuman fungsional meningkatkan kadar protein bersamaan dengan meningkatnya persentase penambahan teh hijau. Hal ini disebabkan kadar protein pada teh hijau tinggi yaitu $18,18 \%$. Pada penelitian terdahulu juga menyebutkan bahwa interaksi antara protein susu dan flavonoid pada teh hijau dapat meningkatkan kadar protein. ${ }^{20}$

Kandungan asam amino pada bahan-bahan minuman fungsional saling melengkapi, dimana pada susu kedelai memiliki delapan asam amino esensial, yaitu lisin, triptopan, fenilalanin, leusin, isoleusin, treonin, metionin dan valin. ${ }^{28}$ Asam amino pada madu yaitu proline, memberikan kontribusi sebesar $50-85 \%$ dari total asam amino yang terdapat dalam madu. ${ }^{29}$ Teh hijau juga memiliki asam amino yaitu theanine. ${ }^{22}$

Sebuah penelitian melaporkan jumlah lisin, sistein dan triptofan yang terdapat pada kedelai mengalami penurunan setelah berinteraksi dengan 
senyawa fenolik yang berbeda. ${ }^{18}$ Soya glycine dan soya trypsin inhibitor diderivitisasi oleh senyawa berstruktur $\mathrm{C}_{6}-\mathrm{C}_{1}$ yaitu epigalokatekin galat (EGCG). ${ }^{18}$ Hal ini tentu akan mempengaruhi bioavailabilitas asam amino esensial dalam sistem pangan. Penelitian lain juga melaporkan bahwa tanin menurunkan daya cerna protein secara in vivo dan in vitro. ${ }^{31}$ Interaksi antara tanin dan protein menghambat enzim pencernaan dan daya cerna protein.

\section{Organoleptik Minuman Fungsional Teh Hijau, Susu Kedelai dan Madu Warna}

Minuman dengan penambahan teh hijau sebanyak 2\%, 3\% dan 4\% dinilai netral oleh panelis. Warna minuman yaitu hijau tua, semakin banyak penambahan teh hijau, semakin pekat warna yang dihasilkan. Warna pada minuman ini disebabkan oleh kandungan klorofil pada teh hijau sehingga berwarna hijau. ${ }^{8}$ Teh hijau yang digunakan yaitu dalam bentuk bubuk atau lebih dikenal dengan matcha, sehingga warna hijau yang dihasilkan lebih terlihat dibandingkan dengan teh hijau yang diseduh air panas.

\section{Aroma}

Pada parameter aroma, penambahan teh hijau sebanyak 2\%, 3\% dan 4\% dinilai netral oleh panelis. Aroma khas dari teh hijau terjadi karena reaksi asam amino (L-theanine) dengan katekin pada temperatur tinggi menghasilkan aldehid, selain itu juga adanya asam organik dan substansi resin yang terkandung dalam teh hijau. ${ }^{8}$

Minuman kontrol masih beraroma langu, walaupun pada saat proses pembuatan sudah menggunakan metode penggilingan panas (hot grinding) pada suhu $80-100^{\circ} \mathrm{C}$. Aroma langu disebabkan oleh enzim lipoksigenase yang ada dalam kedelai. Enzim lipoksigenase dapat menghidrolisis asam lemak tak jenuh ganda dan menghasilkan senyawa-senyawa volatil, khususnya etil-fenil-keton. $^{7}$

\section{Rasa}

Pada parameter rasa, semakin banyak penambahan teh hijau maka semakin tidak disukai. Hal ini disebabkan karena minuman fungsional terasa pahit (bitter-aftertaste) meskipun sudah ditambahkan madu. Rasa pahit diperoleh dari kandungan kafein dan L-theanine dari teh hijau. ${ }^{22}$ Citarasa dari bubuk teh hijau (matcha) diperoleh dari pengolahan yaitu mengukus, pengeringan, menghilangkan batang, pelepah dan serat daun kemudian digiling halus (fine grinding) dengan penggilingan batu. ${ }^{27}$

Untuk minuman kontrol disukai oleh panelis karena rasanya yang manis. Rasa manis pada minuman kontrol berasal dari madu. Rasa manis madu diperoleh dari kandungan gula penyusunnya, asam-asam organik dan jenis nektar. Madu mengandung $41 \%$ fruktosa, $35 \%$ glukosa dan 1,9\% sukrosa. ${ }^{13}$

\section{SIMPULAN}

Penambahan teh hijau pada minuman fungsional susu kedelai dan madu menurunkan aktivitas antioksidan dan menaikkan kadar protein secara bermakna.

\section{DAFTAR PUSTAKA}

1. World Health Organization. Global status report on noncommunicable diseases 2010. Geneva: World Health Organization. 2011. Available from URL : http://www.who.int/nmh/publications/ncd_report_f ull_en.pdf

2. World Health Organization. Global atlas on cardiovascular disease prevention and control. Geneva: World Health Organization. 2011. Available from URL : http://whqlibdoc.who.int/publications/2011/97892 41564373_eng.pdf

3. World Health Organization. The Impact of chronic disease in Indonesia. Facing the facts 2002 [cited 2015 January 20]. Available from URL : http://www.who.int/chp/chronic_disease_report/m edia/impact/indonesia.pdf

4. Rahma, S., Rosdiana N, dan Peter K. Pengaruh antioksidan madu dorsata dan madu trigona terhadap penghambatan oksidasi LDL pada mencit hiperkolesterolemia. JST Kesehatan Vol. 4 (4): 377-384, Oktober 2014

5. Redha, A. Flavonoid: struktur, sifat antioksidatif dan peranannya dalam sistem biologis. Jurnal Berlian Vol. 9(2): 196-202, September 2010

6. Mudjajanto, E.D., dan Fauzi RK. Susu Kedelai yang Menyehatkan. Cet.2 Depok: PT. Agromedia Pustaka. 2006

7. Astawan, M. Sehat dengan hidangan kacang dan biji-bijan. Jakarta: Penebar Swadaya. 2008

8. Syah, ANA. Taklukkan Penyakit dengan Teh Hijau. Cet. 1. Jakarta: PT Agromedia Pustaka. 2006

9. Yamamoto, T., Juneja LR, Chu DC, and Kim M. Chemistry and applications of green tea. Boca Raton, USA: CRC Press, LLC. 1997

10. Kao, Y.H., Hiipakka RA, and LiaoS. Modulation of endocrine systems and food intake by green tea epigallocatechin gallate. Endocrinology 141: 980 987. 2000

11. Weiss, D.J., and Christopher RA. Determination of catechins in matcha green tea by micellar electrokinetic chromatography. Journal of Chromatography A, 1011: 173-180. 2003

12. Gheldof, N., Xiao-Hong W, and Engeseth NJ. Identification and quantification of antioxidant components of honeys from various floral sources. 
Journal of Agricultural anf Food Chemistry 50: 5870-5877. 2002

13. Sihombing, DTH. Ilmu Ternak Lebah Mau. Bogor: Gadjah Mada University Press. 1997

14. Rohman, A. Prosedur Analisis Komponen Makanan. Yogyakarta: Graha Ilmu. 2013

15. Rahayu, W.P. Penuntun Praktikum Penilaian Organoleptik. Jurusan Teknologi Pangan dan Gizi. Fakultas Teknologi Pertanian. IPB. 1998

16. Ozgen, M., Reese RN, Tulio AZ Jr, Scheerens JC and Miller AR. Modified 2,2-Azino-bis-3 ethylbenzothiazoline-6-sulfonic acid (ABTS) Method to measure antioxidant capacity of selected small fruits and comparison to Ferric Reducing Antioxidant Power (FRAP) and 2-2-Diphenyl-1picrylhydrazil (DPPH) methods. Journal of Agricultural and Food Chemistry 1151-1157. 2006

17. Arts, M.J.T.J., Haenen GRMM, Wilms LC, Beetstra SAJN, Heijnen CGM, Voss HP, et al.. Interactions between flavonoids and proteins: Effect on the total antioxidant capacity. Journal of Agricultural and Food Chemistry 50: 1184-1187. 2002

18. Rawel, H.M., Czajka D, Rohn S, and Kroll J. Interactions of different phenolic acids and flavonoids with soy proteins. International Journal of Biological Macromolecules 30: 137-150. 2002

19. Jianhui, Y., Fangyuan F, Xinqing X, and Yuerong L. Interactions of black and green tea polyphenol with whole milk. Food Research International 53: 449-455. 2013

20. Yuksel, Z., Elif A, and Yasar KE. Characterization of binding interactions between green tea flavonoids and milk proteins. Food Chemistry 121: 450-456. 2010

21. Winarsi, H. Protein Kedelai dan Kecambah Manfaatnya Bagi Kesehatan. Yogyakarta: Kanisius. 2010

22. Heiss, ML. Matcha the gossamer tea powder of Japan. The Leaf 4: 20-24. 2008

23. Lisa, R., and Sheera S. Comparison of the effect of different types of soya milk on the total antioxidant capacity of black tea infusions. Food Research International 44: 3115-3117. 2011

24. Dubeau, S., Samson G, and Tajmir-Riahi HA. The effect of milk on the antioxidant capacity of green, Darjeeling, and English breakfast teas. Food Chemistry 122: 539-545. 2010

25. Serafini, M., Ghiselli A, and FerroLuzzi A. In vivo antioxidant effect of green and black tea in man. European Journal of Clinical Nutrition 50: 28-32. 1996

26. Park, D.J., Imm JY, and $\mathrm{Ku} \mathrm{KH}$. Improved dispersibility of green tea powder by microparticulation and formulation. Journal of Food Science 66: 793-798. 2001

27. Tokunaga, M. New tastes in green tea: A novel flavor for familiar drinks, dishes, and desserts. Kodansha USA Inc., New York, USA. 2004
28. Santoso, B.H. Susu dan Yogurt Kedelai. Yogyakarta: Kanisius. 1994

29. Hermosin, I., Rosa M., Chicon M., and Dolores C. Free amino acid composition and botanical origin of honey. Food Chemistry 83: 263-268. 2003

30. Velayutham, P., Anandh B, and Dongmin L. Green tea catechins and cardivascular health: an update. Curr Med Chem 15(18): 1840-1850. 2008

31. Ozal, T., Esra C, and Filiz A. A review on proteiphenolic interactions and associated changes. Food Reasearch International 51: 954-970. 2013 